\title{
EVALUATION ON THE EFFECT OF LAND TAX PAYMENT POLICY TOWARD GROSS DOMESTIC PRODUCT IN BANYUWANGI DISTRICT: A STUDY ON THE DRIVE THRU TAX PAYMENT SERVICE IN REVENUE OFFICE OF BANYUWANGI DISTRICT
}

\author{
Anoraga Abiseka*, Supriyono Bambang, Wijaya Andy Fefta \\ Faculty of Administrative Science, University of Brawijaya, Indonesia \\ *E-mail: abisekaa@gmail.com
}

\begin{abstract}
This study is an evaluative study on the policies implemented by district government in optimizing the public service offered to the public related to the tax revenue earned by the district especially the revenue from the land tax. The land tax policy has been implemented based on the law and regency-level policies applied in Banyuwangi. This study mainly focuses on the evaluation of the land tax payment system through the drive thru service and its effect toward the tax revenue earned by the district. This study employed the interactive research design using descriptive qualitative method. The result of this study shows that the tax payment system using drive thru has been optimally administered yet more payment counters are needed to enlarge the scope of the tax service especially to reach taxpayers in villages. In addition, there has been improvement on the amount of the revenue earned by Banyuwangi distict from the land tax which is beneficial to support the development of the regency.
\end{abstract}

\section{KEY WORDS}

Evaluation on tax payment policy, land tax, property tax, district.

One of the major revenue sources which supports the development of districts/regencies is the gross domestic product. The amount of the gross domestic product has a strong influence on the independence of a district. Besides, the gross domestic product also has a significant effect on the local budget which is used to improve the prosperity of the people. Zauhar (1996:3) explained that problems related to public administration are getting more complicated and more varied in the terms of quality and the quantity as well. The central government is also aware of the importance of the gross domestic product in supporting a nation.

The independence given to district government in managing districts' revenue is ruled by the law number 28 year 2009 about local taxes and local retribution (Pajak Daerah dan Retribusi Daerah / UU PDRD). District government is expected to be able to create policies based on the law. Dye (in Soenarko, 2000:8) stated that "Public policy is whatever governments choose to do or not to do". Similar view was stated by Titmuss (1974, in Suharto (2008:7) in which policy is defined as a set of principles that rule certain actions directed to achieve certain objectives. In addition, land tax which used to be managed by the central government has been changed and given to the district government to be managed. The revenue from the land tax is quite a lot. However, the improvement on the amount of the revenue from the tax should be followed by the improvement on the taxation service for the public. According to Parasuraman (2001), the concept of the service quality refers to the satisfactory and the dissatisfactory of the service offered. Meanwhile, Moenir (2000: 16-17) stated that public service refers to the process to fulfill certain necessities through activities done by other people. In a study conducted by Wijaya and Oscar (2014: 1), it is stated that how human conduct management on the public-sector organizations is called public management. A public service is called high qualified when it goes beyond the expectation, while the quality is stated satisfactory when it has some better aspects than the expectation.

Regarding to the implementation of the law number 28 year 2009 about local tax and local retribution, Banyuwangi district has reviewed the law in order to receive the authority on the management of land tax properly to improve the district revenue which also improves the 
district budgeting According to Pramono (2010:3), the state's budget is directly managed by the state, while the district revenue is under districts' direct management. Therefore, district regulation of Banyuwangi number 6 year 2012 about land tax and housing tax in villages and cities has been created. Soemitro (in Rismawati et.al (2012:2) stated that tax is a contribution paid by residents for the nation which is ruled by legal law (coercive) without given direct return (contra-achievement), and it is used to fund public necessities. The regulation rules the management of the taxation to give significant improvement on the district revenue.

The quality of the service is the most important point to optimize the role and the proactiveness of taxpayers in paying their taxes. By considering some socio-cultural factors and the condition of the society, in 2013, the government started to apply an innovation on modern tax payment system in the form of drive thru service. The implementation of the new service is ruled by the decision letter issued by the Head of the Revenue Office of Banyuwangi (Kepala Badan Pendapatan Kabupaten Banyuwangi) number 970/5034/429.116/2012 about the policies of public service on land tax payment using "Drive Thru" innovation in Banyuwangi district. Widjoyo (2013:4) mentioned that drive-through or drive-thru is a service provided by certain business owners that allows customers to buy products or services without having to step out from their cars.

In order to support this innovation, some other supportive factors are needed such as the quality of the human resources, technology, payment process, and so on. Some of those factors have been fulfilled by the revenue office to offer faster, efficient and effective payment system for taxpayers in paying their tax. Besides, the real condition on the field showed good response from the public toward the existence of tax payment counters that help them paying their land tax through the drive thru service. Evaluation on the implementation of this innovation was done to see factors that needed improvements to offer better services. Subianto (2007) stated that evaluation can be used to analyze factors that cause violation. Thus, the result of the evaluation on the land tax payment system using the drive thru service can be used as a guide to create betterment of the policy. The result can also be used as an insight to seek for solutions for problems that occur in the implementation of this system. Furthermore, this evaluation was also done to identify problems occurred in the field in order to be able to find the solutions. This evaluation also attempted at knowing expectations and complains about the policy on land tax payment system using the drive thru service.

\section{METHODS OF RESEARCH}

Moleong (2009) stated that research that intend to understand any phenomena which is experienced by subjects of the study such as behavior, perception, motivation, action in a holistic using description in the form of verbal language is called naturalistic research. In this study, the researcher employed an interactive research method within the umbrella of descriptive qualitative research approach. The focuses of this research included: (1) Evaluation on the policy of land tax payment system through the drive thru service as an attempt to improve the taxation service in Banyuwangi district (2) The effect of the land tax payment service through the drive thru toward the improvement of the gross domestic product (3) Factors that support the improvement on the quality of the land tax payment service. This research was done in Banyuwangi city particularly in the Revenue Office of Banyuwangi District. The data of this study were in the form of primary and secondary data. The primary data were obtained from interviews with informants, observations and documentation. Meanwhile, the secondary data were taken from books, documents on the city plan, journals and scientific articles. The researcher played role as the key instrument and employed interview technique to collect the data. Other supportive tools to collect the data were in the form of notes and recorder. In this study, the researcher employed the qualitative research method as proposed by Miles, Huberman and Saldana. The data analysis was conducted through four steps which were the data collection, data presentation, data condensation, and conclusion or verification. 


\section{RESULTS AND DISCUSSION}

Evaluation on the Policy about Land Tax Payment using the Drive Thru as an attempt to improve the taxation service for taxpayers in Banyuwangi District. Evaluation on the land tax payment service using the drive thru is an assessment on the policy implemented by the government of Banyuwangi district to improve the taxation service for taxpayers. The service of the tax payment system using the drive thru done by the government of Banyuwangi district is not only to fulfill the need of taxpayers but also to educate the taxpayers. It is necessary to conduct evaluation to see the effectiveness of this program and to identify the problems occurred in the implementation of this program. According to Dunn (2003), criteria of the evaluation on public service include the effectiveness, efficiency, appropriateness, distributiveness, responsiveness, and preciseness of the service. Supriyanto (2007:209) pointed out that the evaluation or assessment refer to the integrated part of certain management function that is done based on certain information management system. In addition, Casley and Kumar (in Wahab, 2001: 23) explained that evaluation is a form of assessment done toward certain project performance and its effect on the target group or target area. Furthermore, Anderson (in Winarno, 2008: 166) stated that generally, evaluation on certain policies deals with making estimation and assessment that cover the substances, implementation, and the effect of the policies. The implementation of land tax payment through the drive thru service offers ease of access and effectiveness for the public.

The implementation of tax payment through the drive thru service has been considered to offer more effective and efficient process. Tax payment through the drive thru service is differing in the effectiveness of the process in which taxpayers are offered with easy Standard Operational Procedure (SOP) of the system. The benefit of the drive thru service does not only apply for taxpayers as the public who find paying tax through the drive thru service easier and faster, but the government especially the revenue office also finds it beneficial since they receive the fund more quickly.

The innovation of tax payment service through the drive thru service is also the solution for various problems which used to occur in the previous tax payment system. The technology innovation has encouraged the government to design the drive thru tax payment service. The old system required tax officers chosen by the head of village to collect the tax from taxpayers. However, this system cannot meet the need of the people living in cities, besides it is no longer appropriate to use in this modern era. The implementation of this innovation has been made regarding to the factors related to those who offer service (revenue office) and those who receive the service (public). This policy offers an alternative for taxpayers to pay their land tax. One of the considerations related to the necessity to conduct evaluation on the implementation of the drive thru tax payment service was the need to know if the drive thru service has been accessible for all of the taxpayers in Banyuwangi District. In fact, the drive thru service has not yet been accessible for some people. Regarding to the fact that any taxpayer pays the tax, the ease of access should also contain the basic principle of fairness. Even though the data showed that the people give good and positive responses toward the land tax payment system through the drive thru service and it also shows that the service has been able to motivate taxpayers to pay their tax, this evaluation was still worth conducting. This innovation is implemented related to the view that the land tax payment service was dissatisfactory for the taxpayers. Innovation that offers better service should be implemented since taxpayers have fulfilled their obligation to the nation with the tax amount set by the government based on the applied rules.

The Effect of Land Tax Payment (Pajak Bumi dan Bangunan / PBB) through Drive Thru Service toward the Improvement on the District Revenue (Gross Domestic Product). The land tax payment system through the drive thru service is closely related to the public interest especially related to public service which will play some effect on the parameters to analyze the success of the program in providing the public with the expected service. The same matter also applies to any policies related to tax collection and retribution which are important revenues that determine the development of a district/regency. Yani (2002:49) underlined that any income and outcome that belong to districts' management in a certain 
year should be put into the districts' budgeting as stated in the law number 33 in 2004 about balancing the finance between the central government and district government (Perimbangan Keuangan antara Pusat dan Daerah Pendapatan Asli Daerah, Pendapatan asli daerah) which is called as district revenue. The government has set a certain target on the amount of land tax obtained from the taxpayers based on the potencies that exist in a district/regency. The percentage of taxpayers paying their tax through the drive thru service has reached over $85 \%$. This fact shows that the public participation to the innovation is quite positive. In addition, the land tax payment system through the drive thru service also improved the district revenue. It can be seen from the data showing that more than $70 \%$ of the total land tax were paid by taxpayers through the drive thru service and the rest were paid through the Bank Jatim.

In addition, land tax payment through the drive thru service appears to be a bridge or a way to increase the amount of the revenue obtained by Banyuwangi District. Although the increase on the revenue is not quite high, it cannot be said low either. With the increase on the amount of land tax by $\pm 15 \%$ every year, the land tax contributes $\pm 20 \%$ or more than 20 Billion Rupiah to the total district revenue which is considered huge and strong enough to give maximum contribution to the development of the district.

Factors Contributing to the Enhancement on the Quality of Land Tax Payment Policy. The success of the land tax payment through the drive thru service is result of supports from several parties with the revenue office as the leading sector. The implementation of this policy has also been supported by the revenue office as the internal sector which has tried to optimize its potency by improving the quality of the human resource. Furthermore, the government has also utilized the advancement of technology and applied a simple set of procedure in the process of land tax payment through the drive thru service. The support from external parties in improving the quality of the service includes the support from Bank Jatim which has given the personnel as the counter tellers. The public has also given the support in the form of awareness in paying their tax to the district. Without the participation from the people, this innovation would not be successfully implemented.

\section{CONCLUSION}

The conclusion of this study entitled "Evaluation on the Land Tax Payment Policy and Its Effect toward the Improvement of District Revenue of Banyuwangi District" are:

The policy about the land tax payment service through drive thru service is the realization of the attempt to improve the quality of tax payment service for taxpayers. This innovation offers alternative ways for taxpayers to pay their tax through the drive thru service. The result of this evaluation shows that the drive thru service offers simpler and more effective procedure for the taxpayers in paying their land tax. Better efficiency offered by the drive thru service does not only benefit the taxpayers but it also gives significant benefits for the government as the tax collector and tax manager. The drive thru tax payment service does not directly replace the manual tax payment regarding to the fact that the drive thru service is not yet able to cover and reach all taxpayers in all over the district.

The shifting on the land tax payment ownership from the central government to the local government has made the land tax becomes a big potency to improve the district revenue. The drive thru service implemented by the government of Banyuwangi District has given positive and significant effect on the optimization of land tax collection. The positive participation from the public automatically improves the amount of the tax paid which improves the revenue from land tax. This can be seen from the construction of the land tax to the district revenue which amount improved significantly. The improvement on the amount of revenue from land tax is expected to keep increasing each year. The target can be achieved when the effectiveness on the tax payment process is well maintained and improved using the drive thru service.

The improvement on the quality service offered by the drive thru payment system is influenced by intern factors and extern factors. The intern factors include the support given by the government of Banyuwangi district in the form of drive thru tax payment system 
followed by massive socialization of this new system done by the revenue office, and improvement on the quality of the human resources and utilization of advanced technology. The extern factors are the supports given by Bank Jatim and the awareness of the people to pay their tax obligation.

\section{REFERENCES}

1. Dunn, William. 2003. Pengantar Analisis Kebijakan Publik. Yogjakarta: Gajah Mada University Press.

2. Hariadi, Pramono, Yanuar E. Restianto, Icuk Rangga Bawono. 2010. District Revenue Management. Jakarta: Salemba Empat.

3. Moenir, H.A.S. 2000. Public Service Management in Indonesia. Jakarta: Bumi Aksara.

4. Moleong, J Lexy. 2009. Metode Penelitian Kualitatif. Bandung : PT. Remaja Rosdakaya.

5. Parasuraman, A.Valerie. 2001. Delivering Quality Service. New York: The Free Press.

6. Soenarko, S.D. 2000. Public Policy (Basic Understanding for Comprehension and the Analysis of Government' Policies). Surabaya: Airlangga University Press.

7. Subianto, E.Utama, S.J. 2007. Evaluasi Kebijakan Retribusi Parkir di Kecamatan Banyuwangi Kabupaten Banyuwangi. Aplikasi Administrasi, Vol.9 No 1 hal. 35

8. Sudirman, Rismawati dkk. 2012. Taxation: Theoretical Approach and Practices). Malang: Empat Dua Media

9. Suharto, Edi. 2008. The Paradigm of Social Welfare Studies. Conference Paper. Bandung.

10. Supriyanto, S., Damayanti, N.A. 2007. Planning and Evaluation. Surabaya: Airlangga University Press.

11. Wahab, Solichin Abdul. 2001. Public Policies Evaluation. Second EditionMalang: UM Press.

12. Widjoyo, Iksan Ongko. 2013. An Analysis on the Effect of Service Quality toward Consumers' Satisfaction on the Drive Thru Service of McDonald's at Basuki Rahmat in Surabaya, The Journal of Marketing Management Vol.1 No.1

13. Wijaya, Andy Fefta \& Danar, Oscar. 2014. Public Management: Theories and Practices. Malang: UB Press.

14. Winarno, Budi. 2008. Public Policies: Theories and Process. Jakarta: PT Buku Kita.

15. Yani, Ahmad. 2002. Financial Correlation between the Central Government and District Government in Indonesia. Jakarta: Grafindo.

16. Zauhar, Soesilo. 1996. Public Administration. Malang: Penerbit IKIP. 